\title{
Jale Ghaemmaghmi: An Outstanding Social- Political Poet in Contemporary Persian
}

\author{
Dr Raha Zareifard, Dr Mehdi Rezaei
}

Assistant Professor, Faculty of literature and Humanities, Jahrom University, Iran

Associate Professor, Faculty of literature and Humanities, Salman Farsi University of Kazerun, Iran

\begin{abstract}
Jale Ghaemmaghmi is the late Ghajar and first Pahlavi poet who has social-political thought and is the outstanding poet among female poets. However, she is anonymous as the consequence of her limitation in her life. By studying her poems, it is found that her social-political thought is in line with some famous thinkers such as Dehkhoda, Bahar and Kasravi. She has more social poems in comparison to Forugh Farokhzad. This paper aims at investigating her thought by categorizing her poems to introduce the hidden layers of her thought to contemporary researchers in literature and sociology.
\end{abstract}

Key terms: Jale Ghaemmaghmi, Alamtaj, Dehkhoda, Forugh Farokhzad, Social Poem, Political Poem.

Language: English

Date of Submission: 2018-04-15

Date of Acceptance: 2018-04-20

Date of Publication: 2018-04-30

ISSN: 2348-3024

Volume: 09 Issue: 01

Journal: Journal of Advances in Linguistics

Website: https://cirworld.com

This work is licensed under a Creative Commons Attribution 4.0 International License. 


\section{Introduction}

Alamtaj (Jale) Ghaemmaghmi is the grandchild of Ghaemmagham farahani who is vanguard in simple writing. She is one of the contemporary poets who has no fame until her son, Hossein Pejman Bakhtiari, collected her poems and add it to Persian literature repertoire. She shared some great social-political thought with Dehkhoda. She was born in 1902 in famous family. When she was five-year old, she started the education (Karachi, 2004: 129). Her teacher was "Jenab" and since she was very clever and genius, Jale has learned Persian and Arabic reading and writing, morphology, syntax and semantics in a very short time.

When she was only 16, her father forced her to marry Alimorad Khan (40-year indelicate army man). Jale and her husband have nothing in common and most of her poems involve him.

Finally, after the first birthday of her son, she divorced and returned to her father's home. She felt so lonely there, since her husband did not let her to see her son. After 18 years, she found him and after a short time passed away.

\section{Data and Methodology}

The data of this article consist of:

A) Divan, the collection of only 917 couplets which display her skill in Persian literature. Pejman Bakhtiari has collected and printed her scattered poems amidst her notes and books. Jale's poems are in the form of ode and stanza. She has just a poem in the form of lyric in her poetical works.

B) Lyrics, A poetical works of her lyrics that she has destroyed because she believed that lyric is the language of love and her love life has been denied.

After studying these data, her social and political thoughts categorized in many groups and compared with her contemporary thinkers.

\section{Social and political thoughts}

Concerning the current situation and tribulation of reforming is the pillars of important political thought of each thinker; because intellectuals deal with human and chronic issues of mankind. In the words of Glenn Tynder, the main persistent question of human is political thought and attitude (Tynder, 1995: 4) and "Political ideas are formed within the context that rose by the essential questions of human society" (Jamshidi, 2006: 156).

Jale has comprehended six kingdoms of the Iranian government. She was born twelve years before the murder of Naser Aldin Shah. She remembered those days which are coincided with the period of the formation of her character. After him Mozafar Aldin Shah and Constitutional Revolution and the spread of newspapers and news events affected the young poet. Mohammad Ali Shah's era and the shelling of the parliament and minor autocracy has opened tumultuous period in her life. Finally, Ahmad Shah and his quiet government and the establishment of the Pahlavi and his reforms Such as unveiling and extensive relationship with the West, certainly had a direct effect on this educated and informed lady. Finally, World War II, coincided with the end of her life. The youth of Mohammad Reza Shah and the empowerment of civil society and the growth of democracy in the early years of his rule, were equal to Jale's final days. These great social events have made Alamtaj to a quite social and political poet who was trying in desire to reform her society through poetry. Of course, "the rising and going six kingdoms at the life of Alamtaj in 63 years, and occurrence of social and political events in the Qajar period and the rise of Mohammad Reza Pahlavi" (Farazmand, 1983: 33) have had important role in shaping her political and social ideas. 
Jale views at social issues frequent and mockery disharmonies and her language in this field isare reckless. Regarding the different social sectors and anomalies in all its dimensions, she made herself responsible and criticized herself.

\subsection{Misperception of religion}

The greatest suffering that poets have so far, is misconception and irrational and sometimes malicious view of religion. This point makes wrath the free and liberal poet and consequently by brilliant poems, she criticized trifled religion by some people. Jale was aware of the religious sciences and the social and intellectual antecedents. She criticized this injustice that some malevolent people have been done against religion:

"Our religion was helpful for the majority of weak but now works for the strong, mirror"

"I can say with whom that the poor-catching God has been consistent with poor- molten people, mirror"

"Makes rich to grow dominance over you and us by a great way, mirror"

(Karachi, 2004: 77)

She sings elsewhere against wanton and justifies the religion of their unstoppable desires:

"The woman also claimed concubines and is Muslim at the same time, but this is just a lust"

(Karachi, 2004: 86)

She explicitly knew that such impression of religion that men have imposed for misusing religion is wrong. She believed these rights that some salacious men misplaced and wrong interpretations of religion, are outside the context of religion and the verses of holy Quran. She further, by knowledge and her science of the religion, has condemned misconceptions and bad behavior through debate:

"The right of men separated from religion, our particular religion although now is in the palm of force"

"This holy book, and that you, be ashamed. Say where your claim as Islam is?"

"When did God sign injustice for butterfly? When did prophet of God want such a poor woman?"

(Karachi, 2004: 41)

Complaining the wrong interpretation of religion is not certain for Alamtaj as if this is a pervasive phenomenon that even her contemporary, Dehkhoda, also responsed. Dehkhoda in this regard believes that the truth of religion is the base and rejects the blind worship: "Yes, it is unfortunate that a nation is unaware of the true religion and worshiping and blind obedience is forced" (Arian Pour, 2000: 84).

\subsection{Criticizing the government}

Main Constitutional cry of patriotism and social-political criticism are in the connection with the homeland and the country. This cry has been heard in the poems and writings of people like Farrokhi, Eshghy, Bahar and Dehkhoda. Jale, meanwhile, objecting to the separation of some parts of the country, screamed to inefficient people who carry the Name of the Kings. She, in the poem verses below, ridiculously is addressing herself that you do not know the secrets of the government and kings know them. While in some lines, about their incompetence and inability to protect the country represents:

"You lose the Caucasus region easily but at the field of the claim make passion and melee" 
"The defeat of the Romans like the defeat of the Arabs with commemoration of mine you deny suddenly"

"In the defeat of MARV there is no place of denying or you want to pretend that it is also a victory"

(Karachi, 2004: 48)

Such a fighting with the government was the issue that all the constitutionalists were looking for. The climax of these objections can be seen in Dehkhoda's papers. He explicitly says: "During the lifetime he is monitoring events of the time and always wishes for country's independence, freedom, progress and perfection." (Ahmadi Givi, 1996: 104). He challenges the base of the throne with rational and transmitted arguments and reasons in a serious article that writes at seventh number of Sour Israfil newspaper in exile.

\subsection{Fight against oppression}

Injustice that comes from the government to people offends the tender heart of the familiar-pain poet. She composed verses to alleviate her hearts and register in history.

"Alas no refuge nor judgment to women in this dark region"

(Karachi, 2004: 36)

"Till resurrection there are two under life behind the poor and desolates, mirror"

"Subordinates oppressed from superiors because the powerful dictates, mirror"

"Eat or eaten, kill or killed, it is indisputable in the world, mirror"

(Karachi, 2004: 78)

\subsection{Science seeking}

Jale's sinew mixed with science from childhood. The welfare of her young days and attribution of her family on great Ghaem Magham Farahani caused that she seeks science and praises the science anywhere and in any language.

"He speaks but about knowledge. You are in glory of your ancestors"

"O son of Bu-Ali, Razi's generation, from what you are disgracing of your fathers"

(Karachi: 2004: 48)

This positive approach about the west is not particularly for Alamtaj; but also, other constitutional scholars looked at the West in the natural sciences and mathematics and humanities with admiration. For instance, Dehkhoda in his satirical article refers to west scientific advances and industries. (Dehkhoda, 1994)

\subsection{Avoidance of pride in the past}

Extreme nationalist trend which was widespread among some intellectuals at constitutional time, not only does not help Iran's progress in the long term but causes prevalent hostility and dispute among religious groups and political thinkers.

Alamtaj meanwhile lines expressed the extreme nationalist view and criticized it. Although she lives with nationalist husband, she maintained her independent thought and has not been affected by his thoughts; an 
idea that is strongly welcomed and supported by the community. She also criticized her husband for the irrelevant national pride and glory prejudice to the past.

"Ferdowsi and Shahnameh and that book are poetry..."

"Alexander's conquest and the Arab's, if there isn't legend, it'll be an imagination"

"That the robber escaped to Greece, where has a door on rich country"

"From the glory of his ancestors, he boasts to the world"

(Karachi, 2004: 35)

\subsection{Avoiding laziness}

Another social weak point is indolence and avoiding economic and social activity or in a simple word, laziness. Jale knows this world as a battlefield that man must struggle to achieve their demands and avoid laziness to win the chance ball.

"Rejection would be happened from you as a woman because there's no rewards but rejection and deny"

"Life intertwined eat and sleep, but sleep and eat would not be suppressors of all life"

"Do an effort, ambition, excitement, rebellion, attempt. the world is nothing but arena of battle"

(Karachi, 2004: 18)

\subsection{Anti-superstition}

Superstition and ignorance, as a pernicious poison, have corrupted some ideas in Jale's point of view. She is pessimistic about ancient astronomy, astrology and geomancy and blames them. This benevolent Iranian lady like Dehkhoda combats prevalent superstition in society.

"You say our garments and fortune and luck is only in the hand of witches round the desert"

"Fascinated him and his sweet words but if ask him the truth there is not except the cold look"

"I've known so much of the fortune-teller that his credibility in my work is not more than Kaaba"

"And astronomy taught me a point that I tell you. No one's day is brighter than stars"

(Karachi, 2004: 18)

Dehkhoda has also expressed that "Islamic Extensive cleared facts were mixed with severe contents of mysticism and poetic waste fallacies of the religion, illusory, myths and habits. Unfortunately, superstitions found its way into the hearts of believers brutally while Islam was outdated any superstitions." (Arian Pour, 1998: 85).

\subsection{The nature of woman}

Alamtaj draws an accurate picture of the nature and social position of women by thought and clear and logical wisdom. It's interesting that she just knows many weaknesses of women and does not overlook them and accepts many of the shortcomings of the woman. She calls everyone to work together and cooperate to solve their problems. 
"In the world of women, delight in life is just to live with the love of the sweetheart"

"Sharing in sorrow and joy of sweetheart"

(Karachi, 2004: 29)

She knows that there are inherent and innate differences between women and men and refers two of them including long life and blunt intellect. This fair poet criticizes women's cunning and coquetry repeatedly and behind the makeup items, reveals women's real face and sullenness covered by beautiful coloration. Our liberal poet refers to the coward of women that makes a woman to recover it and turn into a snare.

"Who is the woman? What is the actor and plaything? Gem baseless mixed by clay"

"Low activity in the years of her life and her mind is later-full and at present is in the future regret"

"Sullenness is covered with adornment and poor spirit is mixed by gimmick"

(Karachi, 2004: 25)

\subsubsection{Self weakness}

Among all female intrinsic defects, Alamtaj takes the finger on her inner self weakness and powerless. She knows it better than anything to be modified.

"Female is incarnate humility and the man is illustrated proud"

"This is optional to get you away from myself and it is God demands that I'm bad"

"Yes, he is a man and I'm a woman. The woman is a victim of misery"

(Karachi, 2004: 36)

\subsubsection{Chastity and decency}

While Jale is looking for women's freedom and writing poems about it, strongly disagrees with debauchery and promiscuity and condemns promiscuity with harsh tone. Her purpose and explanation of women's freedom is social freedom within the framework of religious and Iranian values. At the time of Reza Shah's reforms and Modernism, Jale calls Iranian women and girls to observe chastity and virtue and separates social Freedom from reprobation. She, in condemnation of unchaste women of her time, attacks them and says:

"I describe a Baghdad ballerina who rejects the name and the ancestry"

"Tress is scattered on the shoulders and her breast is bare and ravish the heart"

(Karachi, 2004: 84)

Alamtaj is a pioneer in religious intellectuals in Iranian women. Obeying her Iranian and Islamic culture, she believes that the veil and chador are not obstacle on the way of socialization. She thinks chastity and the veil and Islamic dress do not impede social activities and believes that

"Do not think that chador is obstacle because my cry is raised from black veil"

(Karachi, 2004: 109) 
But she in contrast to fanaticism and social cutbacks that it can be observed anywhere in her book, represents that If the veil that is self- confidence-cause, prevent your success fire it.

"If your life was vanished by veil, fire it even if man of religion called you pagan"

(Karachi, 2004: 109)

She has also criticized the veil elsewhere if impede from progress:

"The woman is a stigma because covered by sticky black veil"

(Karachi, 2004: 36)

She believes in chastity and in response to a rep man who intends to make unconventional relationship with her, with a strong and the authority of an Iranian woman answer the unanswerable.

"After that suitable item you are greed to join me? Really stupid"

"You are our neighbor more than six years; what wrong behavior have you seen foolish guy?"

(Karachi, 2004: 124)

But these lines are not due to the retrogression of Jale; she has a very clear vision and progenitor of chastity. She distinguishes the differences between chastity, modesty, backwardness and social backwardness. She blames hypocrisy for chastity and believes that mandatory veil has no value:

"Chastity has led the superiority over the rest of the people that is very valuable"

"If you know virtue as your art, you are wrong since virtue is your duty"

"If Chastity is true it will be famous so stay away from indulgence to be real"

(Karachi, 2004: 85)

\subsection{Women restrictions}

Jale complains at the restrictions that society imposes on women and at this competition she has no respects. She objects to everything and everybody even the misconceptions and erroneous interpretations of the religion's laws and whips reckless on violators of women's rights. She knows the limitations as an evil towards women. She believes the right of women at the male-dominated society has been violated; rulers have been involved in this injustice and have taken the side of the oppressor.

"Constraints of Chastity and tradition and religious and custom are only ornaments of women not men"

(Karachi, 2004: 17)

Jale with a picture of prison-like poems, as Massoud Saad Salman's lines, sees herself as a confined and screams at the reactionary rulers from the depths of isolation:

"I'm proud but because I am the woman, as if no one not"

"In the shrine such as monuments, wrapped shrouded around myself like a thorn"

"There is a city and whirl across my prison. I'm in the city and it's not available for me" 
"I have come to visit the prison walls and closed my breath and covered my thoughts"

(Karachi, 2004: 8-37)

"It is not seem right to live in cramped space and say about thoughts"

"You have to be huddled in prison"

(Karachi, 2004: 29)

Jale although clearly does not name policy and rulers and their role in isolation of woman about the causes of these limitations, shows line and course corrections by finding the roots of social cutbacks to statesmen. One of the reasons is physical differences between men and women that make spoiling the rights of woman and bullying the man. She complains about the patriarchal society of her time and believes that the woman is the plaything desires of man.

"The woman is the reckless plaything desires of man. The good and the trick is inevitably her capital"

(Karachi, 2004: 45)

She invokes to religion way in these verses to prove the accuracy of her claim and mentions the meaning of the famous Hadith of the Prophet (PBUH) who said" Paradise is under the feet of mothers"as a witness and condemns the community that has gone the wrong way from the statement of their Prophet. She believes that to recover lost rights, time should not be stopped trying. It is painful for Jale that the woman with all the greatness and unity with man is forced to play into the hands of men and her own lack of human and social rights:

"The woman, to pleasure of man, have no rights other than life"

"Compromises like a dog with Ugly and the Beautiful and like a cat with young and old ones"

"How long should we live like slaves, storing for pleasures of the man"

(Karachi, 2004: 30)

\subsubsection{Social freedom for women}

Her childhood and youth coincided with the first cultural clash between Iran and the West and gradually penetrated the cultural patterns of the West in Iranian society. One of the patterns of Western culture in Iran had a serious impact is cover and social rights of women that with the support of political activists penetrated into Iranian homes. Even homebound and isolated and unobtrusive Jale also be affected. Most probably her poems about lack of freedom for women and their social limitations, belongs to before the formation of Pahlavi government. She has repeatedly called women to follow Western culture and defend their social rights:

"Women has community and Energy in the West, but in our land if all women be together as a people they do not have one's power"

"But the weakness of spirit and poor confidence and defect think made us such existing we deserve"

(Karachi, 2004: 17)

She looks longingly to women's liberation abroad and wail that the woman worth less than dough in Iran

"It is said that women in the West is dangerous but is nothing in Iran" 
"Granted that the woman has much chance in the West but there is not lightening on my house"

(Karachi, 2004: 67)

Of course, she has knowledge about her own cultural and socio-political differences of Iran. She expresses her own wishes, but also notes a little about difficulties and differences that:

"Perhaps what I said about the West and the necessity of living like them"

"Must, but there is difference between the West and Iran for living"

(Karachi, 2004: 20)

But at the same time, she doesn't see herself and other Iranian women far apart those social freedom. She sings:

"Freedom of the woman comes from the West to the East, but it is clear for me in my place"

(Karachi, 2004: 108)

Many important thinkers of our time are concerned about woman's freedom from the man-made trammel; whether male or female. It is important that wisdom dictates to equality between men and women; but several thousand year old traditions prevent the realization of this equality. Efforts must be made to achieve social freedom. She has been dedicated herself and her poems to this important thing and knows this freedom is not easy to achieve. She considers women essential to achieve this unity and integrity:

"Girls get up and unite. My poetry will guide"

"Do not think that veil stops you because my yelling is raised from it"

(Karachi, 2004: 109)

She puts a bright future in the eyes of women and makes them hopeful to the near and shining future and with her intelligence predicts the future of Iranian women:

"Today's girl will not be tomorrow's girl of Iran. Whether you want or not I will release"

"Finally, this plaything woman dominates on men and my enamel will be full of wine to enjoy"

(Karachi, 2004: 108)

"My freedom is like an emerging child and pleasantly sleeps in the lap of today"

"I thought of this and it was a dream, I dream of the day when such blessed day is coming"

(Ibid: 109)

She knows her poems are similar to a child who will grow into her arms and achieve maturity in promoting freedom. Elsewhere she wishes prosperity for women, and represents:

"The life of you who are unborn, God willing, will be more optimistic"

"We hadn't had the pleasure house; your Palace of life will be illuminated" 
"The woman will come out from the bondage of man and become equal if not beyond"

(Karachi, 2004: 119)

Mehrtaj Rakhshan has also poems which indicate the status of Iranian women in the constitutional period. She was among the first freedom fighter women. Her artistic presence in newspapers and magazines of that era is palpable:

"Sometimes your body is covered by torn shirt that is like a shroud for you"

"Does not sweet your mouth sorrow and suffering which comes on the wheel of life"

"Women aware of their civil rights to protect civil rights"

Dari Tondary is also one of those poets who wrote poems about issues such as freedom, peace and war, and reform of maternity home and property. He had traveled much of the world and was familiar with Arabic and French. World deprived -class women are of the sense of his responsibility and shouts that:

"In this country, Women's liberation is incomplete, European in this case are the leading"

"Benefit comes from the sunlight of civilization in the universe, why Iran is in the darkness of barbarism century"

(Babachahy, 2007: 62)

\subsubsection{Encouraging women to unite}

Despite all the criticism that Alamtaj knows about the females, she believes that it is not the right of the woman to be at this lower social rank and always encourages women to strive to achieve their rights. In her last line of the previous part, encourages women to achieve their rights. This concept has repeatedly stated, and the causes of their neglecting are their lack of unity and she insists that women come together to achieve their rights:

"How good if women show kindness about their fellow human beings."

"Or the seeds of hope will plant in the hearts of each other"

"Or like men at this House of pride know herself Important"

"If women support each other, they will succeed"

(Karachi, 2004: 120)

It's seen by her intelligence until a woman economically and financially depends on man will be failed to achieve their social rights. That's why she knows the first step to achieve economic independence through civil partnerships.

"As long as we're poor and withdrawal and inferior of man there is no way but obeying the mighty man"

"So, if your husband is not great that is your crime because that donkey-man is not a prisoner of you but your king"

"High spending and high sundries and low income will be hungry the woman and you're still lewd" 
(Karachi, 2004: 67)

Union is not only what Jale asked but Dehkhoda calls everyone to unify and says " ... In my opinion one Iranian's opinion could have an effect on all of Iran. We should try for solidarity programs and bind tightly to a string that the winds of events cannot scatter us "(Rezvan nezhad, 1998: 9-258).

\section{10. Condemnation of man}

Jale cries for the conflicts of her time that men have dominated women. They are inferior and worthless in the patriarchal society. Many verses throughout her book said that the man is not worthy of the right that the society is given to him.

"Where are licentious eyes and perception of beauty? He behaves like any fatuity animal"

(Karachi, 2004: 82)

Jale explicitly says that man is like the ignorant animals that looking at woman only with lust. She does not blame man for this disability but believes that the instinct of man has made him such humiliated and ignorant:

"I told wrongly that the husband was not guilty. Temptation has captured him"

"Desire or love has heavy locked at a little wisdom of that woman-love man"

(Karachi, 2004: 83)

Accordingly, she believes that misguiding is the nature of man and he has no choice to get rid of those. The traditional and old view of man always bothers Jale. The insight that constrains the woman; So that even some men by others are ashamed to mention the name their mistress and use sarcastically as "children" or "our house" instead of woman and wife:

"He who has called woman "baby" or "our home", how can see that it is genital of man"

(Karachi, 2004: 41)

It means that the women's limitations and her isolation behind closed doors of the harem are due to his short view that they cannot see their partners in the community with other men.

"Among these faithless Muslims there are warm tears and cold sighs and yellow face upon us"

(Karachi, 2004: 17)

He addresses men with a polemic logic that man should be so foolish to think that the woman was created only for his lust. At following lines, she advises other women through exhortation and feminine language that take their revenge from their husbands. Jale sees himself beyond the men because she can have something to say like men in the world:

"The woman was created for the pleasure of men, laughing at these unaware ones"

"Man, from head to toe is malicious vanish, this brutal creature"

"Make hard the life for your brutal husbands without sorry"

"Damage his property and destroy his house" 
"Although it is not possible but if the husband is good you will be good too"

(Karachi, 2004: 122)

However, in some cases, she looks the actual position of women and men and disappointedly accepts bitter social realities:

"It is said that if a man is a good man he is a God for woman"

"Yes, he is a man and I'm plaything and poor the woman"

(Karachi, 2004: 122)

\section{10. 1. Features of the man's appearance}

Jaleh mentions some criteria for the appearance of men and ideal features that are the desire of most women of her day. Contrary to many beliefs, big and rough and rugged man is lauded by her and the soft-tempered men will be disgusted and apparently this is characteristic of most women of her age:

"Visiting death is better for me to be a wife of safflower and yellow hair and softens skin and thinning voice husband"

(Karachi, 2004: 89)

And at this regard, non-beautiful features for a man are illustrated and to one of her friends who thought she was jealous says:

"I see your husband as a casein I am not interested in such non-salt cheese"

"Ruddy and yellow hair and fat and short so I do not want him"

(Karachi, 2004: 66)

In addition to the gracefulness, appreciated man for Jale must possess the characteristics of transcendental moral man. She noted some good moral qualities of man that indicate overview of women and their real desires. She finally considers the characteristics of real man in this way:

"Every man who has clear spirit, good character, strong hands, and holy nature is superior to the woman"

"He is chivalry filled, pure love, honest soul with the wife and good-hearted with friends"

"Good for you if you have such a husband. And if this is not your husband is a stranger"

(Karachi, 2004: 87)

\section{11. The Discrimination between men and women}

Jaleh also expressed the discrimination between men and women. She points out the false morality common among the men of her time that have surpassed from religion and commit the most heinous immorality.

"If the man is insane passion of Love of woman he deserves. Because he is a man and he is superior to the question and answer"

"But if a woman is a little deviated, the people permit themselves to kill her" 
"But the man has neither shame nor fear from doing evil because his selfishness and evil lust is ruling"

(Karachi, 2004: 40)

\section{12. Disapproval of marriage}

The bad habits of the past in the Iranian society that has ever existed, is early and compulsory marriage. Alamtaj, based on her own experiences, criticizes these two types of marriage and tries to inform people about the social and cultural disadvantage of this egregious error. The misery and misfortunes that women see in their lives and her bitter personal experience about the marriage has caused Alamtaj always looked at marriage by dissatisfaction and opposed it. She, at the beginning of her marriage, will complain this way:

"What happened if I do not marry what if I had not caught myself into trouble?"

"Do I interfere? My father would be sad if I did not marry"

"That good husband was more worthless than an animal. I wish I'd never married"

"He was not old and frugal and violent, but I shouldn't marry to such an immature man"

(Karachi, 2004: 19)

The last verse is the main poet's concern about early marriage. She repeatedly attacks this social evil phenomenon and has been warned people. She protests forced marriages performed by dissatisfaction and she believes that in these marriages, mothers agree not daughters:

"Although apparently, we are satisfied with the marriage, mother makes it happen"

(Karachi, 2004: 86)

As mentioned before and chaos divine tradition of marriage which is mixed in an inconsistent way with religion and wisdom in Iranian society; she mocks marriage and says:

"This is marriage or prostitution? Death or life?"

(Karachi, 2004: 30)

Leaving marriage is not particularly for Alamtaj and effect of her personal life; but other contemporary female poets of her time also have been viewed with suspicion and even hatred in marriage such as Forough who said:

"The little girl said with a laugh what is / the secret of this golden ring / the secret of this ring that my finger / has been such tighten / the secret of this ring that has on her face / such radiation and luminosity / the man was bewildered and said: / happiness ring. Life ring / all said congratulations / she replied that alas, I / have still doubt on the meaning / years passed and a night / a depressed woman looked at that golden ring / she saw at the luminous face / days that in hoping for loyalty of husband / has been wasted / was troubled and moaning and that woe / woe this ring which on her face / again is radiation and luminosity / slavery and servitude ring (Farrukhzad, 2004: 7-96)

\section{Conclusion}

1. Contrary to common belief about Jale, she is not a poet of isolation and staying at home woman but is a lady aware of the situation of her time that in different parts of social life is not only ahead of her time but also in social innovation is equal to talents such as Bahar and Dehkhoda. 
2. She is arguably one of the religious thinkers that with her extensive knowledge of the religious fundamentals and intimacy with the Qur'an and familiarity with Arabic language, has a stable view away from superstition and heresies of religion.

3. She encouraged women to participate in social affairs. Her views are the most interesting and unique; because unlike many intellectuals of her time she believes that girls and women must appear and act in social affairs retaining the Veil and Cover as chador.

4. Her dedication to legal affairs and women's modesty is commendable. Unlike many Iranian women poets, all over her Divan is full of feminine spirit, but at the same time preventing any immodest font and language.

5. While she is offended from her partner in life, in dealing with men and ethical characteristics of women, she is quite fair and free from prejudice.

\section{References}

Ariyanpur, Y, (2000). From Saba to Nima. Tehran: Zavar.

Ariyanpur, Y, (2000). From Nima to our Days. Tehran: Zavar

Ahmadi givi, H, (1996). The Selection of Dehkhoda's Work. Tehran: Ghatre

Babachahy, A. (2007). Today's Poem, Today's Woman. Tehran: Vistar.

Dehkhoda, A.A. (2001). Charand and Parand. By Akbar Mortezapur. Tehran: Attar. (1994). Dehkhoda Dictionary. Tehran: Tehran Univercity \& rowzane Press.

Farazmand, H. "The image of Jale in Dusty Mirrors". Ettelaat. November 8, 2006.

Farrukhzad, F. (2004). The Collection of Poems. Tehran: Shadan.

Jamshidi, M.H. (2006). The Face of Thinking: The Methodology of the cognition of Political Thinking. Tehran: Kolbe Marefat.

Kabiri, N. (1993). Sunsets. Shiraz: Navid.

Karachi, R. (2004). Alamtaje Ghaemmaghami. Shiraz: Dastansara.

Rezvannezhad, M.A. (1998). Four National Outstanding Politicians. Tehran: Guttenberg.

Taghi, S. (2008). Earthy Verses of Love. Tehran: Sales.

Tynder, G. (1995). Political thinking. Translated by Mahmood sadri. Tehran: Sientific and Cultural Press. 